\title{
PASAR BEBAS DI ERA GLOBALISASI DALAM PERSPEKTIF EKONOMI SYARIAH
}

\author{
Hoddemah \\ Yayasan Pondok Pesantren Putri an-Nuriyah Wonocolo Utara \\ Surabaya \\ wiwik@steikassi.ac.id
}

Wiwik Saidatur Rolianah

STEI Kanjeng Sepuh Gresik

wiwik@steikassi.ac.id

\begin{abstract}
The free market in the era of globalization is a necessity that cannot avoid. Countries that cannot meet their own needs must trade with other countries to meet these lacking needs. This free market is expected to improve the economy of a country and the welfare of its people. Still, in subsequent developments, the free market will positively impact the perpetrators and have a negative effect so that there will be contraception among economists regarding the merits and demerits of the free market. So far, a country can't stay away from the free market so how a country must make innovation, creativity, work levels, and everything good and quality so that its merchandise can compete in the free market. In Islamic economics, the existence of a free market is allowed to meet the needs of a country while still paying attention to the principles of trade in Islam such as being honest and not doing things that are contrary to religious teachings such as monopoly.
\end{abstract}

Keywords: Free Market, Islamic economy, globalization.

\begin{abstract}
Abstrak: Pasar bebas pada masa globalisasi merupakan suatu kebutuhan yang tidak bisa dihindari. Negara yang tidak bisa memenuhi kebutuhannya sendiri memerlukan adanya perdagangan dengan negara lain untuk memenuhi kebutuhan yang kurang tersebut. Adanya pasar bebas ini diharapkan dapat meningkatkan perekonomian suatu negara dan mensejahterkan rakyatnya tapi pada perkembangan selanjutnya pasar bebas tidak hanya berdampak positif bagi para pelakunya tapi juga berdampak negatif sehingga terjadinya kontrasepsi antar para ekonom mengenai kebaikan dan keburukan pasar bebas. Sejauh ini, suatu negara tidak bisa menjauh dari pasar bebas sehingga bagaimana suatu negara harus membuat inovasi, kreativitas, tingkat kerja, dan segala sesuatu yang baik dan bermutu agar barang dagangannya dapat bersaing dalam pasar bebas. Dalam ekonomi Islam, adanya pasar bebas diperbolehkan untuk memenuhi kebutuhan suatu negara dengan tetap memperhatikan asas-asas perdagangan dalam Islam seperti jujur dan tidak melakukan hal yang bertentangan dengan ajaran agama seperti monopoli.
\end{abstract}

Kata Kunci: Pasar Bebas, ekonomi Islam, globalisasi.

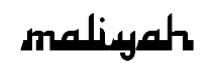

Jurnal Hukum Bisnis Islam

Volume 8, Nomor 2, Desember 2018

p-ISSN: 2088-4869/ e-ISSN: 2597-4351 


\section{Pendahuluan}

Perekonomian dunia saat ini tidak bisa terlepas dari globalisasi. Secara sederhana, fenomena ini disebut "revolusi ekonomi" yang menghasilkan dunia tanpa batas (bordereless) sehingga sebagian kecil dari dampaknya adalah dengan adanya pasar bebas. ${ }^{1}$

Pasar bebas adalah perdagangan antara individu-individu atau perusahaan-perusahaan di negara yang berbeda tanpa adanya hambatan. Tulisan ini, menganalisis tentang pemasaran global di era globalisasi dalam perspektif ekonomi syariah. Yang mana pemasaran global bermula dari adanya suatu kebijakan perdagangan secara teoritis rasionalisasi akan menguntungkan negara berkembang sepanjang waktu, namun banyaknya perbedaan mengenai pemasaran global tidak membuat para ahli ekonomi berganti pikiran mengenai pemasaran global yang bisa membuat perekonomian yang makmur. Juga bagaimana IMF (International Monetary Fund), BTO (Build, Transfer, Operate) dan Bank Dunia menangapi semua ini dalam neo-liberalismenya, dan yang lebih penting lagi mengenai pandangan Islam terhadap pemasaran global ini.

Pemasaran global bermula di Inggris dan lebih luas lagi di Eropa yang telah memicu adanya pemasaran global yang lebih besar di tingkat global hingga tahun ini. Jangkauan pemasaran global telah meluas, negara maju dan berkembang tak terkecuali sama-sama merasakan dampak pemasaran global tersebut. Berita tentang penerimaan dan penolakan adanya pemasaran global telah diberitakan.

Banyaknya pembicaraan mengenai pemasaran global yang sekarang diterapkan di seluruh dunia dan pembahasannya dalam negara maju ataupun berkembang serta dampak positif dan negatifnya, maka dari itu semua kami tertarik untuk membahas tentang pasar bebas (free trade) yang berkaitan dengan pandangan Islam.

\footnotetext{
${ }^{1}$ Joko Siswanto, "Menggagas Globalisasi (Mempertimbangkan Kearifan Lokal Menghadapi Dampak Kesejagadan) Dalam Seminar Siapa Takut Berfilsafat?," Seminar, December 2004.
}

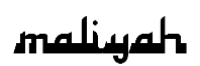

Jurnal Hukum Bisnis Islam 


\section{Hakikat Pasar Bebas}

Pasar bebas (free trade) adalah perpindahan barang dan jasa di antara negara-negara tanpa rintangan politik atau ekonomi. ${ }^{2}$ Pasar bebas dipraktekkan di dunia karena tidak akan ada negara, bahkan yang berteknologi maju sekalipun yang dapat memproduksi semua produk yang diinginkan dan dibutuhkan rakyatnya, misalnya suatu negara yang mampu memproduksi alat-alat berteknologi tinggi tapi tidak bisa mengelolah sumber daya alamnya maka negara ini harus melakukan hubungan jual beli dengan negara lain (adanya free trade) untuk memenuhi kebutuhan hidupnya.

Ada juga yang mengartikan bahwa pasar bebas adalah perwujudan sistem kebebasan kodratif dan keadilan yang dipelopori oleh Smith yakni sistem pasar bebas akan berfungsi sebagaimana mestinya sebagai sebuah sistem sosial yang harmonis, justru karena ditunjang oleh keadilan sebagai aturan main paling utama yang minim bagi interaksi bisnis para pelaku ekonomi. Sistem pasar bebas merupakan sistem sosial harmonis yang menyerupai tatanan kosmis (tertata dengan rapi).

Adam Smith yang dikenal sebagai Bapak politik ekonomi yang terkenal dengan teori mengenai sistem pasar bebas mengatakan bahwa secara ontologis dan moral, pasar bebas merupakan perwujudan kebebasan kodrati dan keadilan, atau merupakan perwujudan hukum kodrat dalam bidang ekonomi. Dengan kata lain, kebesaran pasar bebas terletak pada aspek moral di baliknya.

Menurut Friedrich A. Von Hayek, yang dikutip dari buku Pasar Bebas Keadilan Dan Peranan Pemerintah Telaah Atas Etika Politik Ekonomi disebutkan bahwa hakikat pasar bebas itu membedakan antara sebuah ekonomi dalam pengertiannya yang ketat dan ekonomi pasar bebas. Sebuah ekonomi, seperti sebuah keluarga atau perusahaan disebut sebagai ekonomi, melayani hanya satu tujuan. Sebuah ekonomi dalam pengertian

\footnotetext{
${ }^{2}$ William G. Nickel, Pengantar Bisnis (Jakarta: Salemba Empat, 2009), 77.
} 
ini selalu berupaya untuk mencapai satu tujuan akhir yang sudah jelas ditentukan. Sebaliknya, ekonomi pasar bebas tidak mengenal adanya tujuan satu-satunya yang harus dicapai. Sebuah ekonomi dalam pengertian sebenarnya, kata Hayek, adalah sebuah organisasi taxis yaitu sebuah usaha sadar untuk mengerahkan segala daya dan upaya yang telah diketahui untuk mencapai tujuan tertentu. Sebuah pasar bebas justru sebaliknya adalah sebuah tatanan spontan, yang tidak pernah dapat dikendalikan oleh satu tujuan tunggal. Pasar melayani beragam tujuan yang terpisah-pisah dan bahkan tidak dapat diperdamaikan satu dengan yang lainnya. ${ }^{3}$

\section{Sejarah Pasar Bebas}

Pasar bebas berawal dari pengembangan pasar terbuka. Perkembangan budaya banyak dipengaruhi oleh adanya transaksi perdagangan. Kebijakan adanya pasar bebas dapat menguntungkan negara berkembang. Teori ini muncul di Inggris dan Eropa, semnejak lima abad yang lalu. Dalam pandangan para ahli ekonomi, pasar bebas dipercaya dapat mempengaruhi kebudayaan dan memakmurkan ekonomi warganya.

Adam Smith contohnya, menunjukkan kepada peningkatan perdagangan sebagai alasan berkembangnya kultur tidak hanya di Mediterania seperti Mesir, Roma, dan Yunani tapi juga Bengal dan Tiongkok. Kemakmuran besar dari Belanda setelah menjatuhkan kekaisaran Spanyol, dan mendeglarasikan perdagangan bebas dan kebebasan berpikir membuat pertentangan merkantilis/perdagangan bebas menjadi pertanyaan paling penting dalam ekonomi.

Sedangkan globalisasi ekonomi yang identik dengan pasar bebas secara arkeologis lahir dari pemikiran modern abad pencerahan yang pertama kali di usung oleh Descartes. Metode Descartes merupakan esensi dari kesederhanaan: meragukan segala sesuatu kecuali apa yang hadir dengan sendirinya pada

\footnotetext{
${ }^{3}$ Sonny Keraf, Pasar Bebas Keadilan Dan Peran Pemerintah Telaah Atas Etika Politik Ekonomi Adam Smith (Jakarta: Kanisius, 1996), 198.
} 
pikiran secara langsung dan jelas, merumuskan masalah sebanyak mungkin, merekonstruksikan seluruh masalah itu selangkah demi selangkah, melakukan proses induktif, dan menyebutkan satu demi satu serta mencatat segalanya. Manusia dapat menguraikan empat langkah sekaligus: abstraksi, analisa, sintesa, dan kontrol. ${ }^{4}$ Tujuannya tidak sekadar pengetahuan, tetapi juga kekuasaan dan kemakmuran yang akan membuat umat manusia menjadi "penguasa (tuan) dan pemilik alam" melalui "penemuan beraneka alat yang membuat manusia dapat menikmati buah-buahan dan berbagai komoditas lain " dengan lebih mudah.

Globalisasi dengan neoliberalisme sebagai ideologi dominan yang di aplikasikan dalam pasar bebas bergerak atas dasar metode Cartesian di atas. Penguasaan terhadap alam dan lainnya menjadi dasar pemikiran dan tindakan pasar bebas, karena dari ide muncul tindakan, dan tindakan bergerak atas ide-ide yang menjadi pedomannya. Oleh karena itu, refleksi terhadap ide harus dilakukan apabila dalam prakteknya mengalami banyak penyimpangan, dan menyebabkan kerugian pada sebagian besar individu atau kelompok yang seharusnya mendapatkan perlindungan.

Sebagai instrumen ideologi, pasar bebas percaya dengan efektivitas marginalisasi peran negara sebagai fungsi kesejahteraan menimbulkan serangkaian ancaman terhadap human security. Ketiadaan proteksi dari negara mengakibatkan tidak adanya kontrol atas kelompok lemah, terjadi l'exploitation l'homme par l'homme dengan sosial sebagai alat penggerak. Kemiskinan dan kelaparan di Ethiopia dapat dijadikan contoh menarik kasus ini. Iklim, cuaca, tanah, sering dijadikan kambing hitam permasalahn kronis tersebut. Secara mendasar, janjijanji palsu pasar bebas atas kemakmuran menjadi penyebab utamanya. ${ }^{5}$

\footnotetext{
${ }^{4}$ Bruce Rich, Menggadaikan Bumi: Bank Dunia, Penghancuran Lingkungan, Dan Krisis Pembangunan (Jakarta: INFID, 1999), 223.

5 A. Widyamartaya and AB Widyanta, Globalisasi Kemiskinan Dan

Ketimpangan (Jakarta: Cindelaras Pustaka Rakyat Cerdas, 2004), 129.
} 
Sebagai dampak instrumen hegemoni untuk kepuasan capital, pasar bebas sebagai operasionalisasi globalisasi, secara tidak sadar menjadi ideologi preskripsi keterpurukan ekonomi. Preskripsi yang secara perlahan tapi pasti menjadi racun pemulihan ekonomi negara dunia ketiga.

Sebagai ideologi, pasar bebas hanya dilihat dari sisi praktis. Secara teoretik, di dalamnya mengandung kelemahan dalam memahami masyarakat. Pencerahan sebagai pondasi teoretiknya, dengan ragam rasionalitasnya membawa arah perubahan pada pemeliharan kesenjangan karena masyarakat di lihat sebagai obyek semata. Kontradiksi prediksi-praksis pasar bebas sebagai konsep tersebut menimbulkan kerancuan untuk pengimplementasian.

\section{Campur Tangan Pemerintah dalam Pasar Bebas}

Beberapa kegagalan dari pasar bebas yang seperti dijelaskan diatas, menuntut para ahli ekonomi berfikir tentang campur tangan pemerintah dalam pasar untuk pengaturan kegiatan ekonomi. Campur tangan pemerintah dimaksudkan dengan tujuan:

1. Mengawasi agar akibat ekstern kegiatan ekonomi yang merugikan dapat dihindari.

2. Menyediakan barang publik yang cukup hingga masyarakat dapat membelinya dengan mudah dan murah.

3. Mengawasi kegiatan-kegiatan perusahaan, terutama perusahaan besar yang dapat mempengaruhi pasar.

4. Menjamin agar kegiatan ekonomi yang dilakukan tidak menimbulkan ketidaksetaraan dalam masyarakat.

5. Memastikan pertumbuhan ekonomi dapat diwujudkan secara efisien.

Campur tangan pemerintah dalam ekonomi dapat dilakukan dalam tiga bentuk yaitu:

1. Membuat undang-undang. Undang-undang diperlukan untuk mempertinggi efisiensi mekanisme pasar, menciptakan dasaran sosial ekonomi dan menciptakan pertandingan bebas sehingga tidak ada kekuatan monopoli. 
2. Secara langsung melakukan kegiatan ekonomi (mendirikan perusahaan) dengan produksi barang publik.

3. Melakkukan kebijakan fiskal dan moneter. Kebijakan fiskal diperlukan masyarakat bahwa pemerintah dapat menetapkan anggaran belanja dan penerimaan negara secara seimbang. Kebijakan moneter diperlukan untuk mengendalikan tingkat harga-harga agar tetap stabil. Akan tetapi pada akhirnya kebijakan moneter adalah peranan uang dalam kegiatan ekonomi.

Kebijakan fiskal dan moneter dapat digunakan oleh pemerintah dengan tujuan:

1. Mempertinggi efisiensi penggunaan faktor produksi.

2. Meratakan disribusi pendapatan.

3. Mengatasi masalah-masalah makro ekonomi yang selalu timbul yaitu, pengangguran, inflasi dan lain-lain.

\section{Pasar Bebas dan Kemiskinan Struktural}

Globalisasi yang dibangun atas dasar pondasi modernitas mempunyai cita-cita membangun masyarakat melalui pemberdayaan agresif individu, dan usaha penguasaan terhadap alam, menjadi acuan dalam pembangunan ekonomi dewasa ini. Merujuk pendapat kelompok hiperglobalis, globalisasi ekonomi membangun bentuk baru organisasi sosial tanpa keikut sertaan negara bangsa sebagai lembaga ekonomi utama dan unit politik dari masyarakat dunia. Hal ini tercermin dari pemaksaan penerapan pasar bebas sebagai realisasi pandangan tersebut. Menurut Giddens, hal tersebut disokong gugus penyangga modernitas: kapitalisme, industrialisme, dan control alat kekerasan, dan gugus institusional globalisasi: ekonomi kapitalis dunia, pembagian kerja internasional, sistem negara bangsa, dan tata militer dunia. ${ }^{6}$ Sokongan tersebut semakin memperjelas posisi pasar bebas dalam prosesnya.

Pasar bebas yang dipercaya akan melepaskan kekuatan ekonomi yang terkekang dan membawa pada efisiensi

\footnotetext{
${ }^{6}$ B. Herry Priyono and Anthony Giddens, Suatu Pengantar Kepustakaan Populer (Jakarta: Gramedia, 1997), 61.
} 
penggunaan sumber-sumber daya dunia yang langka, akan membawa pada maksimalisasi pemakmuran dunia dan memungkinkan seluruh masyarakat memperoleh kemakmuran secara ekonomi. Hal ini terjadi akibat efek trickle down yang terjadi secara otomatis karena telah terpuaskannya kebutuhan individu. Selain itu, konsep invisible hand juga menjadi trigger pemusatan penerapan pasar bebas menghambakan pada situasi keseimbangan pasar akibat mekanisme supply and demand.

Dalam hal ini, menurut Bonnie Setiawan, hal tersebut sangatlah mustahil, karena pasar tidak pernah memikirkan mengenai aspek sosial atau agenda penghapusan kemiskinan. Pasar adalah bagaimana menghasilkan profit dan profit. $^{7}$ Karena itu, kemakmuran untuk lainnya merupakan suatu keniscayaan yang hanya dapat dinikmati oleh segelintir orang dengan capital lebih dalam mekanisme pasar bebas. Kondisi demikian memang terjadi, hal tersebut dapat dilihat dari laporan Shukor Rahman Pada Straits of Malaysia Time: [di seluruh dunia] kira-kira 50.000 orang mati setiap hari akibat kurangnya kebutuhan papan/tempat tinggal, air yang tercemar, dan sanitas yang tak memadai. ${ }^{8}$

Selain itu, trickle down effect yang dipercaya akan memberikan kesejahteraan dan kemakmuran kepada lainnya, secara epistemologis hal itu gagal karena ketiadaan batas kebutuhan yang di miliki oleh manusia. Hal ini merujuk pada sifat dasar manusia yang selalu merasa kekurangan.

Kondisi ini dapat menimbulkan pertanyaan, apakah pasar bebas seperti inikah yang menjadi cita-cita manusia sekarang? Karena itu, diperlukan suatu refleksi terhadap konstruksi teoretik globalisasi (pasar bebas) untuk membebaskan dari belenggu kemiskinan dan kelaparan ini. Refleksi ini ditujukan untuk menghancurkan struktur dominasi teoretik yang

\footnotetext{
${ }^{7}$ Bonnie Setiawan, Globalisasi, Utang, Dan Privatisasi Dalam Jurnal Keadilan (Jakarta: Institute for Global Justice, 2003), 16.

${ }^{8}$ Roy Murtadho, "Puasa Dan Semangat Anti Kapitalisme," June 12, 2015, https://islambergerak.com/2015/07/puasa-dan-semangat-anti-kapitalisme/.
} 
menjadi panutannya. Perlu dilakukan karena akan membawa implikasi positif pada penciptaan keadilan tanpa menimbulkan kerugian terhadap pihak lain.

Dalam kaitannya prediksi-praksis teori globalisasi, pasar bebas sebagai jantungnya, mengalami defisit dalam empirisnya. Kontradiksi yang terjadi akibat kesalahan asumsi yang di bangun, tanpa memperhatikan sifat mendasar subyek. Beragam jenis penderitaan yang di alami sebagian besar penduduk di negara dunia ketiga menjadi bukti nyata atas kegagalannya. ${ }^{9}$ Dengan menempatkannya sebagai konstruksi teoretik, pasar bebas mengalami beragam distorsi internal, dan keadaan demikian selalu dengan adaptasi konseptual. Karena itu, kontradiksi ini memberikan sinyal kuat untuk diadakannya suatu bentuk refleksi teoretik secara mendasar untuk melepaskan dominasi dalam tataran ide sebagai langkah awal.

\section{Pro dan Kontra Pasar Bebas}

Banyak ekonom yang berpendapat bahwa pasar bebas meningkatkan standar hidup melalui teori keuntungan komparatif dan ekonomi skala besar. Sebagian lain berpendapat bahwa pasar bebas memungkinkan negara maju untuk mengeksploitasi negara berkembang dan merusak industri lokal, dan juga membatasi standar kerja dan standar sosial. Sebaliknya pula, pasar bebas juga dianggap merugikan negara maju karena ia menyebabkan pekerjaan dari negara maju berpindah ke negara lain dan juga menimbulkan perlombaan serendah mungkin yang menyebabkan standar hidup dan keamanan yang lebih rendah. Pasar bebas dianggap mendorong negara-negara untuk bergantung satu sama lain, yang berarti memperkecil kemungkinan perang.

Alasan-alasan para tokoh ekonomi yang menyetujui adanya pasar bebas, yaitu:

1. Pasar bebas memiliki 6 miliar pelanggan potensial barang dan jasa.

\footnotetext{
${ }^{9}$ Revrisond Baswir, Globalisasi Sebagai Sumber Kesenjangan Ekonomi UtaraSelatan(Yogyakarta: PNMHII XVI UPN Jogja, 2004), 12.
} 
2. Produktivitas tumbuh ketika negara memproduksi barang dan jasa di mana mereka mempunyai keunggulan komparatif.

3. Persaingan impor yang semakin murah membuat harga tetap murah sehingga inflasi tidak mengurangi pertumbuhan ekonomi.

4. Perdagangan bebas menginspirasi inovasi untuk produk baru dan membuat perusahaan terus menerus tertantang secara kompetitif.

5. Aliran modal yang tidak terputus memberi akses negara terhadap investasi asing yang membantu dalam menjaga tingkat suku bungah tetap rendah.

Alasan-alasan para tokoh ekonomi yang menolak adanya pasar bebas, yaitu:

1. Pekerjaan domestik (khususnya di pekerjaan berbasis manufaktur) dapat kehilangan pekerjaan mereka dikarenakan meningkatnya impor atau pengalihan produksi ke pasar bebas yang bergaji rendah.

2. Pekerja dapat terpaksa menerima pemotongan bayaran dari pemberi kerja, yang dapat mengancam untuk memindahkan pekerjaan mereka ke pasar bebas yang berbiaya lebih rendah.

3. Memindahkan operasi keluar negeri karena tekanan persaingan yang intens acap kali berarti hilangnya pekerjaan jasa dan pertumbuhan jumlah pekerjaan kerah putih.

4. Perusahaan domestik dapat kehilangan keunggulan komparatif mereka ketika pesaing membangun operasi produksi yang canggih dinegara bergaji rendah.

\section{Peraturan di Indonesia terhadap Pasar Bebas}

Peraturan pemerintah mengenai perdagangan bebas diatur dalam peraturan menteri perdagangan republik indonesia nomor: 20/m-dag/per/7/2011 tentang perubahan kedua atas peraturan menteri perdagangan nomor $45 / \mathrm{m}$ dag/per/9/2009 tentang Angka Pengenal Importer (API).

Secara historis dan idiologis, negara Republik Indonesia mewarisi gagasan ekonomi demokrasi utamanya dari 
pemikiran Muhammad Hatta. Menurut Hatta, selain "demokrasi politik harus pula berlaku demokrasi ekonomi. Kalau manusia belum merdeka, persamaan dan persaudaraan belum ada. Sebab itu cita-cita demokrasi Indonesia ialah demokrasi sosial melingkupi seluruh lingkungan hidup yang menentukan nasib manusia."

Mohammad Hatta dalam bukunya Dasar Politik Luar Negeri Republik Indonesia, mengemukakan bahwa tujuan politik luar negeri Indonesia adalah:

1. Mempertahankan kemerdekaan bangsa dan menjaga keselamatan negara.

2. Memperoleh barang-barang yang diperlukan dari luar negeri untuk meningkatkan kesejahteraan rakyatnya

3. Meningkatkan perdamaian internasional dan memperoleh syarat-syarat yang di perlukan untuk meningkatkan kesejahteraan rakyat.

4. Meningkatkan persaudaraan antarbangsa sebagai pelaksanaan cita-cita yang terkandung dalam pancasila.10

Dalam politik luar negeri Indonesia yang terdapat dalam GBHN 1999-2004 terdapat poin yang menyebutkan untuk meningkatkan kesiapan Indonesia dalam segala bidang untuk menghadapi pasar bebas, terutama dalam menyongsong pemberlakuan AFTA, APEC, dan WTO. Yang mempunyai landasan politik luar negeri Indonesia pada

1. Landasan idiil yaitu Pancasila.

2. Landasan konstitusional yaitu UUD 1945 yang terdapat dalam Batang Tubuh UUD 1945 pasal 11 dan pasal 13.

3. Landasan operasional adalah sebagai berikut:

a. Ketetapan MPR mengenai Garis-Garis Besar Haluan Negara (GBHN) terutama bidang luar negeri.

b. Kebijakan yang dibuat oleh Presiden. Dalam hal ini keputusan Presiden (Keppres) yang menyangkut politik luar negeri Indonesia.

${ }^{10}$ Aim Abdulkarim, Kewarganegaraan (Bandung: PT Grafindo Media Pratama, 2009), 86-87. 
c. Kebijakan atau peraturan yang dibuat oleh menteri luar negeri.

Pada zaman ini ekonomi Indonesia bergerak semakin tinggi pada pasar bebas. Suatu kejadian mengenai kekuasaaan yang berkisar tentang the power of capital yang merasuk kedalam semua dimensi kehidupan. Bagi mereka yang tidak mampu berkompetensi, pasar bebas tidak lebih dari siasat ekonomi kaum globalis untuk memanfaatkan kelemahan sturuktular dalam perekonomian nrgara-negara berkembang melalui sejumlah instrumen yang berkesan manusiawi. Di sisi lain subsidi pangan, tetapan upah minimum, perlindungan buru dan petani, program khusus penciptaaan lapangan kerja, jaring pengaman sosial, dan progaram-program semacam itu merupakan hal tabu bagi ekonomi politik liberal.

Menurut Thomas Friedman dalam bukunya The Winner Take Almarket, ekonomi pasar bebas mengakui hanya persaingan (competition) dan inesiatif individual sebagai penggerak kemajuan ekonomi. Ia mengabaikan kerja sama (cooperation) sebagai penggerak kekuatan ekonomi berdasar mutualitas antar indivudu. Meskipun tidak semua tabiat pasar bebas itu buruk, namun kalau kita bercermin pada kasus Indonesia dewasa ini, banyak akses pasar bebas yang tidak mendukung pencapaian keadilan bagi seluruh rakyat. Ini menyangkut kuatnya praksis distriminatif terhadap mereka yang memiliki produktivitas rendah, merintangi hak demokrasi rakyat (si miskin hanya menjadi penonton), peroyek privatisasi telah melepaskan cabang produksi dan sumber daya ekonomi yang penting bagi negara dan yang menguasai hajat hidup orang banyak ketangan perseorangan, merenggangkan ikatan sosial dan mendorong polarisasi sosial ekonomi yang semakin mengokohkan ketimpangan sturuktural, dan meredukasi nilai manusia hanya sebagai manusia ekonomi yang menempatkan sumber daya manusia tidak lebih sebagai faktor produksi ekonomi. ${ }^{11}$

${ }^{11}$ Komaruddin Hidayat and Put ut Widjanarko, Reinventing Indonesia Menemukan Kembali Masa Depan Bangsa (Bandung: Mizan, 2008), 303-4. 


\section{Peraturan di Indonesia Mengenai Pasar Bebas}

Undang-undang Nomor 1 tahun 2000 tentang kawasan kawasan perdagangan bebas dan pelabuhan bebas, yang membutuhkan bahwa " kawasan perdangangan bebas dan pelabuhan bebas merupakan wilayah hukm Negara kesatuan Republik Indonesia yang pembentukanya dengan Undangundang. Jangka waktu suatu kawasan perdagangan bebas dan pelabuhan bebas adalah 70 (tujuh puluh) tahun terhitung sejak ditetapkan sebagai kawasan perdagangan bebas dan pelabuhan bebas. Dalam kawasan perdgangan bebas dan pelabuhan bebas mempunyai fungsi sebagai tempat untuk mengembangkan usaha-usaha dibidang perdagangan, jasa, inustri, pertambangan dan energi, transportasi, maritime dan perikanan, pos dan telekomunikasi, perbankan, asuransi, pariwisata dan bidang-bidang lainya."

\section{Sejarah dan Teori Liberalisasi terhadap Pasar Bebas}

Sejak lahir di dunia, manusia telah bergaul dengan manusia-manusia lainnya di dalam suatu tempat dan wadah yang bernama masyarakat. Dalam perkembanagan sejarah kehidupan manusia selanjutnya, ditemukanlah berbagai ketimpangan-ketimpangan yang muncul dari perbedaan kepentingan. Karena itu muncullah peraturan-peraturan yang sifatnya mengatur dan melindungi. Ini merupakan bentuk kesadaran manusia yang tertinggi untuk menghargai kepentingan orang lain.

Kemunculan teorinya Adam Smith dan David Ricardo melalui Wealth of Nation merupakan salah satu akibat munculnya kesenjangan ekonomi yang menyatakan bahwa kompetisi dalam perdagangan bebas telah membawa proses kesenjangan ekonomi yang sangat tinggi bagi masyarakat tentang kebangkitan ekonomi yang berkeadilan dengan konsep pasar bebas. Teori liberalisasi yang diinginkannya berusaha menciptakan kondisi manusia yang harus melakukan kompetisi dengan lainnya dalam kepentingan ekonomi. 
Di Indonesia ekonomi neoliberalisme muncul sejak pemerintah orde baru yang diawali dengan berdirinya konsorsium International Government Group on Indonesia (IGGI) atas kerjasama pemerintah dengan Bank Dunia, Dana Moneter Internasional (IMF), Bank PembangunanAsia (ADB), menjelang tahun 1970.

Indikasi tonggak kebijakan Liberalisasi Ekonomi pada era 80 'an

1. Liberalisasi sektor keuangan

2. Liberalisasi sektor Industri

3. Liberalisasi sektor Perdagangan

Kata liberalisasi secara etimologi memiliki kedudukan kata benda sekaligus kata aktif. Sebagai kata benda ia berarti penganut liberalisme yaitu suatu paham atau aliran ketatanegaraan (politik) yang bercita-cita demokrasi dan yang menganjurkan kebebasan berusaha dan niaga tanpa campur tangan dan interfensif pemerintah sedangkan sebagai kata sifat ia bermakna bebas. Sementara secara terminologi, liberal dikenal sebagai suatu pandangan (orang) yang mendesak pemerintah untuk berperan aktif dalam mengubah kondisi sosial dan ekonomi yang tidak benar dan tidak adil. ${ }^{12}$

Dari hal tersebut dapat dilihat bahwa berlakunya mekanisme persaingan pasar bebas merupakan refleksi konsep perjuangan untuk hidup. Konsep persaingan pasar bebas ini melandasi mekanisme pasar bebas, menurut Adam Smith mekanisme pasar bebas akan menjadi the invisible hand atau kekuatan gaib (tidak kelihatan) yang secara tidak langsung akan menciptakan kesejahteraan masyarakat. Kesejahteraan masyarakat tercapai bila tiap individu dapat menikmati kebebasan untuk mengembangkan potensinya. Dengan demikian, individu menjadi pusat usaha. Individu dipandang sebagai sosial otonom yang terpisah dari masyarakat. Keberaadaannya untuk memaksimalkan laba dengan

\footnotetext{
${ }^{12}$ Haiz Najah, "Studi Hukum Islam Tentang Proteksi Perdagangan Di Indonesia Dalam Menghadapi Pasar Bebas" (2000), 21-22.
} 
menggunakan sarana teknologi, sumber daya manusia, sumber daya alam, serta lingkungan. ${ }^{13}$

Dalam tatanan ekonomi global, persaingan pasar bebas di dunia usaha pada umumnya dilakukan atas dasar produktivitas dan harga. Keberhasilan usaha ditentukan oleh kemampuan perusahaan untuk menghasilkan barang dan jasa dalam jumlah yang lebih besar dengan menggunakan sumber daya yang sama atau sedikit. Keberhasilan daya saing juga ditentukan oleh kualitas, keanekaragaman, kesesuaian dengan selera dan kebutuhan konsumen, kenyamanan dan kemudahan yang ditawarkan serta ketepatan waktu.

\section{Dampak Perdagangan Bebas}

Perdagangan bebas memiliki dampak positif dan dampak negatif. Dampak positif diantaranya adalah: Dengan adanya perdagangan bebas yang di lakukan oleh suatu negara, tentunya negara tersebut dapat menikmati produk tidak hanya dari hasil produk buatan dalam negeri sendiri saja, tetapi juga dapat mengkonsumsi produk buatan luar negeri dengan mudah karena dengan adanya perdagangan bebas barang impor dapat bebas masuk kedalam negeri. Selain itu terjalin suatu hubungan internasional yang semakin terbuka antar negara. Kemudian produk-produk dalam negeri dapat dengan memudah meraih popularitas di luar negeri. Dapat pula meningkatkan reputasi negara ketika suatu negara dapat berprestasi menciptakan produk yang bermanfaat dan diminati oleh konsumen internasional.

Kemudian devisa kuat jika ekspor lebih besar daripada impor. Setiap individu bebas memiliki kekayaan dan sumber daya produksi. Setiap individu bebas memiliki kekayaan dan sumber daya produksi, inisiatif dan kreatifitas masyarakat dapat dikembangkan, terjadi persaingan antar produsen untuk menghasilkan barang yang bermutu, efisiensi dan efektifitas

\footnotetext{
${ }^{13}$ Keraf, Pasar Bebas Keadilan Dan Peran Pemerintah Telaah Atas Etika Politik Ekonomi Adam Smith, 197.
} 
tinggi karena tindakannya selalu didasarkan pada prinsip ekonomi.

Tentunya selain dampak positif, tidak sedikit juga dampak negatif yang ditimbulkan akibat kegiatan perdagangan bebas. Yaitu selain menjadi orang yang konsumtif terhadap barang bararang impor, banyak pula pengangguran, karena kalah bersaing produsen dari luar negeri, kemudian banyak pabrik yang bangkrut karena tidak kuat dengan persainan yang begitu ketat, selain itu larinya investor dikarenakan SDM dan ETOS KERJA dalam negeri lemah dan devisa yang habis karena lebih banyak produk impor daripada ekspor.

Kemudian bagi negara-negara yang belum berkembang maka akan menjadi sebuah kerugian karena selalu mengandalkan negara lain untuk terus mengimpor barangbarang kedalam negeri, yang kemudian membuat negara yang lemah ini sulit berkembang karena terus "diserang" oleh barang-banrang impor. Juga sebaliknya, akan menjadi keuntungan tersendiri bagi negara yang telah berkembang untuk terus menjual produknya ini sehingga produknya lebih di minati dan lebih popular di luar negeri. Adanya eksploitasi terhadap masyarakat ekonomi lemah oleh pihak yang kuat ekonominya, menimbulkan terjadinya monopoli sehingga merugikan masyarakat, munculnya kesenjangan ekonomi antara golongan ekonomi kuat dengan golongan ekonomi lemah, perekonomian dapat dengan mudah menjadi tidak stabil.

Contoh Kegiatan Perdagangan Bebas:

1. Perjanjian antara negara-negara Amerika Utara North America Free Trade Area (NAFTA) yang kalau tidak salah beranggotakan Amerika Serikat, Kanada, dan Mexico (meskipun Mexico itu adalah negara Amerika Tengah namun politiknya menjurus ke Amerika ).

2. Perjanjian antara negara negara Amerika Tengah Central America Free Trade area (CAFTA) yang beranggotakan ex Savador, Guatemala dll.

3. Perjanjian antar negara Asean AFTA (ASEAN Free Trade Area) perjanjian antar anggota Asean jadi antar anggota 
harus membebaskan biaya perdagangan antar sesama anggota.

\section{Liberalisasi dalam Islam}

Liberalisasi dalam konteks kebebasan berusaha dan berniaga dalam Islam berkaitan dalam hal perintah Allah dalam Al-Qur'an. Perintah Allah untuk memelihara keseimbangan hidup dengan penyelenggaraan ekonomi, surat Al-Qashash ayat 77:

"Dan carilah apa yang telah dianugerahkan Allah kepadamu (kebahagiaan) negeri akhirat, dan janganlah kamu melupakan bahagianmu dari (kenikmatan) duniawi dan berbuat baiklah (kepada orang lain) sebagaimana Allah telah berbuat baik kepadamu dan janganlah kamu berbuat kerusakan dimuka bumi. Sesungguhnya Allah tidak menyukai orang-orang yang berbuat kerusakan"

Perintah Allah untuk mencari karunianya disegala penjuru bumi, surat Al-Jumu'ah ayat 10:

"Apabila telah ditunaikan shalat, maka bertebaranlah kamu dimuka bumi dan carilah karunia Allah dan ingatlah Allah sebanyak-banyaknya supaya kamu beruntung" Perintah Allah untuk mencari rizqi, surat Al-Mulk ayat 15:

"Dialah yang menjadikan bumi itu mudah bagi kamu, maka berjalanlah di segala penjurunya dan makanlah sebagian dari rezekinya. Dan hanya kepadanyalah kamu (kembali setelah) dibangkitkakan"

Dalam suatu riwayat Anas Ra bahwa Nabi bersabda bahwa:

"Sungguh Allah penentu harga, penahan, pelepas dan pemberi rizqi dan sesungguhnya aku berharap bertemu dengan Allah dalam keadaan tidak seorangpun dari kalian menuntutku karena perbuatan dhalim terhadap jiwa/harga barang". (HR. Ahmad, Abu Dawud, Tirmidzi, Ibnu Majah dan dianggap sahih oleh Ibnu Hibban)

Memang Islam tidak mengenal liberalisasi ekonomi secara tekstual dalam bentuk suatu konsepsi teknis atau ide konseptual Islam mengandung muatan-muatan liberalisasi 
ekonomi sebagaimana dimaksud liberalisasi ekonomi sebagai sebuah sistem. Bahkan kalau dilihat lebih jauh dan obyektif akan terlihat bahwa Islam justru lebih komprehensif dan lengkap dalam menyodorkan beragam aturan dan batasan (moralitas ekonomi) dalam upaya penerapan liberalisasi ekonomi.

Tentu saja terdapat perbedaan didalam prinsip yang diterapkan atau dipunyai keduanya. Dalam Islam individualisme dan kepedulian sosial begitu erat terjalin sehingga bekerja demi kesejahteraan orang lain merupakan cara paling memberikan pengembangan daya guna seseorang dan dalam rangka mendapat ridho Allah SWT.14

\section{Pandangan Ekonomi Islam tentang Perdagangan Bebas}

Agama Islam memiliki ajaran yang menjelaskan secara terperinci prinsip-prinsip yang meliputi semua aspek kehidupan manusia. Dalam perdagangan internasional, Rasulullah telah memberikan contoh tentang hal tersebut. Sejak belia, Rasulullah diajak pamannya, Abu Thalib, untuk berdagang ke Syam dan lain sebagainya. Selain itu, Islam juga mengajarkan umatnya agar melakukan ekonomi secara adil dan seimbang.

Idealisme dari perdagangan bebas tidak jauh dengan ekonom klasik adapun implementasi aktivitas perdagangan internasional tanpa hambatan tarif maupun non tarif akan meningkatkan kesejahteraan masyarakat dunia. Akan tetapi realita telah menunjukkan hal yang sebaliknya, yang mana kesejahteraan yang diraih masyarakat dunia belum rata. Kesenjangan antar dua kelompok ini semakin lebar ketika dunia memasuki era liberalisasi perdagangan. Fenomena ini di gap anatara idealisme dan realitas. Idealisme perdagangan bebas yang dibangun oleh ekonom klasik bersandar pada asumsi yang secara utuh dan tidak sesuai dengan kenyataan, bahwa diantara setiap negara yang hendak berdagang telah

\footnotetext{
${ }^{14}$ Najah, "Studi Hukum Islam Tentang Proteksi Perdagangan Di Indonesia Dalam Menghadapi Pasar Bebas," 61-62.
} 
memiliki kapasitas ekonom yang sama. Meskipun WTO menjadi lembaga perdagangan dunia mengakomodir hal ini dalam pasal-pasalnya, akan tetapi dalam kenyataannya sulit terlaksana secara optimal.

Negara maju yang dibentuk oleh prinsip ekonomi konvensional sering mengemuka melalui argumen yang bernuansa politik. Sementara negara-negara berkembang memiliki kelemahan yang mencakup aspek ekonomi, sosial dan kelmbagaan sehingga tidak memiliki posisi negoisasi dalam pencantuman ekonomi global. Islam telah menawarkan prinsip bahwa perdagangan bebas adalah perdagangan yang mencoba mengoptimalkan hubungan perdagangan dengan luar negeri di lain sisi telah melarang perdagangan komoditas tertentu yang mengganggu kemaslahatan kaum muslim. Islam pun berpandangan bahwa asas perdagangan bebas bukan terletak pada komoditi namun di pelakunya (pedagang). Dengan demikian pemerintahan ataupun negara yang bersangkutan harus memiliki sikap yang jelas dan tegas dalam menjalani perdagangan bebas yang berorientasi untuk kesejahteraan masyarakat.

Sebagai sebuah agama dan ideologi, Islam memiliki sejumlah regulasi mengenai perdagangan luar negeri yang sangat kontras dengan perdagangan bebas: Pertama, aktivitas perdagangan merupakan hal yang mubah. Hanya saja, karena perdagangan luar negeri melibatkan negara dan juga warga negara asing,maka negara Islam, dalam hal ini khalifah, bertanggung jawab untuk mengontrol, mengendalikan dan mengaturnya sesuai dengan ketentuan syariah. Membiarkannya bebas tanpa adanya kontrol dan intervensi negara sama dengan membatasi kewenangan negara untuk mengatur rakyatnya. Padahal Rasulullah SAW: "Imam itu adalah pemimpin dan ia bertanggung jawab atas apa yang dipimpinnya."

Kedua, seluruh barang yang halal pada dasarnya dapat diperniagakan ke negara lain. Meski demikian ekspor komoditas tertentu dapat dilarang oleh khalifah jika menurut ijtihadnya bisa memberikan dharar bagi negara Islam. Misalnya 
ekspor senjata atau bahan-bahan yang bisa memperkuat persenjataan negara luar, seperti uranium, dll. Sebab, komoditas semacam ini bisa memperkuat negara luar untuk melakukan perlawanan kepada negara Islam. Khalifah juga boleh melarang ekspor komiditas tertentu yang jumlahnya terbatas dan sangat dibutuhkan di dalam negeri, sehingga kebutuhan dalam negeri bisa terpenuhi. Dalam kaedah ushul dinyatakan: "Setiap bagian dari perkara yang mubah jika ia membahayakan atau mengantarkan pada bahaya, maka bagian tersebut menjadi haram sementara bagian lain dari perkara tersebut tetap halal."

Ketiga, hukum perdagangan luar negeri dalam Islam disandarkan pada kewarganegaraan pedagang (pemilik barang), bukan pada asal barang. Jika pemilik barang adalah warga negara Islam, baik Muslim maupun kafir dzimmi, maka barang yang dia impor tidak boleh dikenakan cukai. Rasulullah SAW bersabda, "Tidak akan masuk surga orang yang memungut cukai". Namun jika barang yang masuk ke wilayah negara Islam adalah milik warga negara asing, maka barang tersebut dikenakan cukai sebesar nilai yang dikenakan negara asing tersebut ter-hadap warga negara Islam; atau sesuai kesepakatan perjanjian antara negara Islam dengan negara asing tersebut. Namun demikian, demi kemaslahatan Islam, umat dan dakwah Islam, khalifah diberikan kewenangan untuk mengatur besar tarif tersebut. Ketika misalnya pasokan komoditas yang dibutuhkan oleh penduduk negara Islam langka sehingga menyebabkan inflasi, maka tarifnya dapat diturunkan. Dari Abdullah bin Umar ia berkata: "Umar mengenakan setengah 'usyur (5 persen) untuk minyak zaitun dan gandum agar barang tersebut lebih banyak dibawa ke Madinah. Sementara untuk quthniyyah (biji-bijian seperti kacang) beliau mengambil sepersepuluh (10 persen) (HR. Abu Ubaid)."

Keempat, pedagang dari negara kafir mu'ahid (negara kafir yang memiliki perjanjian damai dengan negara Islam), ketika memasuki wilayah negara Islam akan diperlakukan sesuai isi perjanjian yang disepakati antara kedua belah pihak. 
Akan tetapi pedagang dari negara kafir harbi (negara kafir yang memerangi negara Islam, seperti AS, Inggris, India, Cina, Israel, dll), ketika memasuki wilayah negara Islam harus memiliki izin (paspor) khusus.

Kelima, membolehkan perdagangan bebas dengan alasan sejalan dengan Islam, karena adanya larangan Islam terhadap penarikan cukai (al-maks) atas barang impor milik warga negara Islam, tidak dapat dibenarkan. Hal ini karena perdagangan bebas asasnya adalah kapitalisme. Sementara Islam mengharamkan berbagai hadharah yang tidak bersumber dari aqidah Islam meski bisa jadi ada kemiripan.

Keenam, pada kenyataannya perdagangan bebas telah menjadi salah satu strategi negara-negara kapitalis untuk mendominasi negara lain. Sementara di dalam Islam haram hukumnya membiarkan negara-negara kafir menguasai kaum muslim. Allah SWT berfirman: "Dan Allah tidak membolehkan orang-orang kafir menguasai kaum muslim." (QS: an-Nisa [3]: 141).

Pandangan Adam Smith tentang pasar bebas dimana harga ditentukan oleh kekuatan penawaran dan permintaan dalam pasar, diterima oleh pemikir Islam seperti Ibnu Taimiyah dalam bukunya "al-Hisbah". Besar kecilnya harga tergantung pada perubahan permintaan dan penawaran. Hal ini menunjukkan sifat pasar yang impersonal. Bila seluruh transaksi sudah sesuai aturan, maka kenaikan harga merupakan kehendak Allah. Keadilan harga ditentukan oleh berbagai kondisi yang diperlukan untuk memelihara keadilan dalam nilai tukar, yakni harga yang menentukan adalah mekanisme kompetisi normal dan harga bisa ditetapkan lebih dulu dengan mempertimbangkan kebiasaan atau estimasi dari masyarakat. ${ }^{15}$

Islam sangat menekankan keadilan yang terdapat di dalam al-Qur'an. Keadilan dalam harga merupakan perintah Rasulullah seperti dalam kasus majikan yang membebaskan

15 A. A. Islahi, Konsepsi Ekonomi Ibn Taimiyah, Terj. Anshari Thayib (Surabaya: Bina Ilmu, 1997), 104. 
budaknya. Maka dari itu keadilan hanya akan terwujud jika pelaku ekonomi bisnis bertindak secara jujur. Islam sangat menekankan saat bertransaksi harus jujur. Islam juga mengajarkan bahwa kekayaan itu mempunyai fungsi sosial. Dengan tegas al-Quran telah melarang penumpukan harta atau menimbun harta dan melarang mencari kekayaan dengan jalan yang tidak benar serta memerintahkan membelanjakan harta secara baik.

Maka disinilah seorang pelaku bisnis sangat terikat akhlak yang mulia dan menjauhi akhlak tercela yang dapat membhayakan penyebab dari produksi, kebohongan, kecurangan, merugikan orang lain. ${ }^{16}$

Pasar bebas diperkenankan dengan pengawasan dari pemerintah agar tidak terjadi monopoli. Dalam konsep ekonomi dikenal supply dan demand, yaitu ketika permintaan naik dan penawaran tetap, maka harga akan mengalami kenaikan. Hal ini sebagaimana dijelaskan Ibnu Taimiyah: "Apabila orang-orang menjual barang dagangannya dengan cara yang diterima secara umum tanpa disertai dengan kezaliman dan harga-harga mengalami kenaikan sebagai konsekuensi penurunan jumlah barang (qillah al-syai) atau peningkatan jumlah penduduk (kasrah al-khalq) hal ini disebabkan oleh Allah SWT."17

Jadi secara tidak langsung disini pemikir Islam seperti Ibnu Taimiyah telah menyetujui adanya pasar bebas di dunia ini walaupun dengan beberapa ketentuan yang harus dijalankan seperti kebijakan pemerintah.

\section{Penutup}

Dalam perspektif ekonomi Islam, perdagangan bebas boleh dilakukan karena kegiatan perdagangan antar negara

\footnotetext{
${ }^{16}$ Jaribah Ibn Ahmad Al-Harithi, Fikih Ekonomi Umar Ibn Al-Khattab, Terj. Asmuni Salihin Zamakhsari (Jakarta: Pustaka al-Kautsar, 2006), 74-75.

${ }^{17}$ Rindasyayuti, "Ekonomi Islam," $W_{W W}$.

Ekonomi/Islam/Mengubah/Htpwq.Com, May 29, 2010, www.

ekonomi/islam/mengubah/htpwq.com, oleh Rindasyayuti diupload tanggal 29 Juni 2010.
} 
sudah merupakan suatu kebutuhan. Negara yang satu dan negara yang lainnya saling membutuhkan untuk memenuhi kebutuhan negaranya, sehingga dibutuhkan pasar bebas untuk memperlancar perdagangan internasional. Pelaksanaan pasar bebas tersebut tidak boleh bertentangan dengan asas-asas perdagangan dan harus menerapkan strategi dan proteksi yang bagus sehingga tidak menjadi bumerang yang dapat merugikan bangsa.

Pemerintah harus mengontrol dan mengawasi pelaksanaan perdagangan bebas ini, sebagai pengawas yang memantau lalu lintas perdagangan demi kemaslahatan bangsa dan negara.

\section{Daftar Pustaka}

Abdulkarim, Aim. Kewarganegaraan. Bandung: PT Grafindo Media Pratama, 2009.

Al-Harithi, Jaribah Ibn Ahmad. Fikih Ekonomi Umar Ibn AlKhattab, Terj. Asmuni Salihin Zamakhsari. Jakarta: Pustaka al-Kautsar, 2006.

Baswir, Revrisond. Globalisasi Sebagai Sumber Kesenjangan Ekonomi Utara-Selatan. Yogyakarta: PNMHII XVI UPN Jogja, 2004.

Hidayat, Komaruddin, and Putut Widjanarko. Reinventing Indonesia Menemukan Kembali Masa Depan Bangsa. Bandung: Mizan, 2008.

Islahi, A. A. Konsepsi Ekonomi Ibn Taimiyah, Terj. Anshari Thayib. Surabaya: Bina Ilmu, 1997.

Keraf, Sonny. Pasar Bebas Keadilan Dan Peran Pemerintah

Telaah Atas Etika Politik Ekonomi Adam Smith. Jakarta: Kanisius, 1996.

Murtadho, Roy. "Puasa Dan Semangat Anti Kapitalisme," June

12, 2015. https://islambergerak.com/2015/07/puasadan-semangat-anti-kapitalisme/.

Najah, Haiz. "Studi Hukum Islam Tentang Proteksi Perdagangan Di Indonesia Dalam Menghadapi Pasar Bebas," 2000.

Nickel, William G. Pengantar Bisnis. Jakarta: Salemba Empat, 2009. 
Priyono, B. Herry, and Anthony Giddens. Suatu Pengantar Kepustakaan Populer. Jakarta: Gramedia, 1997.

Rich, Bruce. Menggadaikan Bumi: Bank Dunia, Penghancuran Lingkungan, Dan Krisis Pembangunan. Jakarta: INFID, 1999.

Rindasyayuti. "Ekonomi Islam." Www. Ekonomi/Islam/Mengubah/Htpwq.Com, May 29, 2010. www. ekonomi/islam/mengubah/htpwq.com, oleh Rindasyayuti diupload tanggal 29 Juni 2010.

Setiawan, Bonnie. Globalisasi, Utang, Dan Privatisasi Dalam Jurnal Keadilan. Jakarta: Institute for Global Justice, 2003.

Siswanto, Joko. "Menggagas Globalisasi (Mempertimbangkan Kearifan Lokal Menghadapi Dampak Kesejagadan) Dalam Seminar Siapa Takut Berfilsafat?" Seminar. December 2004.

Widyamartaya, A., and AB Widyanta. Globalisasi Kemiskinan Dan Ketimpangan. Jakarta: Cindelaras Pustaka Rakyat Cerdas, 2004. 